\title{
Japan's ODA Policy and Reforms since the 1990s and Role in the New Era of Development Cooperation
}

\author{
Izumi Ohno (National Graduate Institute for Policy Studies (GRIPS))
}

\section{Contents}

1. Introduction

2. The External and Domestic Environment Affecting Japan's Development Cooperation

3. Policy and Institutional Reforms of Japan's ODA in the 1990s through the First Decade of the 2000s

4. Toward a New Era of Development Cooperation:

The Role of Japan in Supporting Country-Specific Growth Strategies, Based on the East Asian Perspectives

5. Conclusion

\section{Introduction}

Japan's development cooperation stands at a crossroads in the face of dramatic changes in both external and domestic environment in recent decades. Now, the international community is actively debating the future development framework after 2015 (the so-called post-Millennium Development Goals [MDGs] agenda). The new era of development cooperation will be characterized by broader and deeper partnerships involving emerging economies and the business sector. Japan should make unique 
contributions to the new era by bringing the East Asian perspectives together with these actors and in a way that reflects Japan's dual experiences as latecomer and donor.

There are several reasons for my argument. First, over the past two and half decades, Japan has made strenuous efforts to build the Official Development Assistance (ODA) institutional framework-initially to make the ODA system commensurate with leading donor (in the 1990s) and later to improve the operational efficiency and transparency of ODA under fiscal stringency (in the first decade of the 2000s). Notable examples are the formulation of ODA Charters $(1992 ; 2003)$ and related policy framework, as well as the establishment of the new Japan International Cooperation Agency (JICA) in 2008 as a single aid agency providing technical cooperation, grant aid and ODA loans in an integrated manner. Furthermore, recent years have seen the creation of new mechanisms for promoting public-private partnerships in development cooperation. Second, the growth agenda has returned to the center of global development debates, after a decade of the poverty reduction drive that dominated the late 1990s to the early 2000s. Japan's aid policy strongly reflects its own historical experience as a successful latecomer country. Japan has long assisted developing countries in attaining self-reliance, sustaining growth and overcoming aid dependency. Successful East Asian economies have adopted growth-oriented development strategies of one kind or another. Many of these economies are now graduating from aid and becoming important players of South-South cooperation. For Japan and other like-minded East Asian donors, regained global balance between growth and poverty reduction, with more emphasis on the former, is highly welcome.

Together with emerging donors and through enhanced partnership with private actors, Japan should actively share the East Asian perspectives of aid and development with interested countries (including policymakers and practitioners, researchers and private sector) by supporting their country-specific growth strategy formulation and implementation. Based on the institutional foundations that have been built in the recent decades, Japan should embark on the new era of development cooperation and play a proactive global role. 
This paper is organized as follows. The first section will review the external and domestic environment that has affected Japan's ODA since the 1990s, namely after the Cold War, and the second section will discuss policy and institutional reforms that took place in this period of two and half decades. The final section will outline key elements of the East Asian approach to development and aid and suggest unique contributions that Japan can make in the new era of development cooperation. Specific reference will be made to the ongoing Japan-Ethiopia industrial policy dialogue, jointly supported by JICA and the National Graduate Institute for Policy Studies (GRIPS). This is a pioneer example of the endeavor to transfer the East Asian development approach to Africa, in which the author has participated as part of the project team for the last four years.

\section{The External and Domestic Environment Affecting Japan's Development Cooperation}

The post-Cold War era has seen significant changes in the environment surrounding international development. With the acceleration of globalization, the development agenda has expanded to include global issues that extend beyond national borders such as climate change, infectious diseases and financial crises. The easing of East-West tensions has caused civil wars and regional conflicts, and the synchronized terrorist attacks of September 11, 2001 (9/11) further raised the importance of supporting fragile states and peace-building to carry on with "the fight against terrorism" in alliance with the United States (US). The aid fatigue syndrome that prevailed during the post-Cold War era forced donor countries and institutions to take concerted actions to elevate "poverty reduction" to the highest international development goal in order to regain public support for ODA. The MDGs orchestrated by the United Nations (UN) in 2000, the Poverty Reduction Strategies (PRS) introduced by the World Bank and the International Monetary Fund (IMF) in 1999, and the harmonized aid approach to enhance aid effectiveness led by the Development Assistance Committee (DAC) of the Organisation for Economic Co-operation and Development (OECD) (from around 2003) 
are three ingredients of this poverty reduction drive, which dominated global aid debates from the late 90 s to the early 2000s.

Development actors have also diversified, leading to the increased complexity of international aid architecture. These include emerging donors such as China, India and Brazil, in addition to South Korea, which has already achieved remarkable development and joined the OECD/DAC in 2010, as well as a variety of private actors such as non-governmental organizations (NGOs), civil society, private foundations and corporations. By now, private actors have come to account for 60-70 percent of the total financial flow into developing countries, far exceeding ODA. The Lehman Shock that hit the world economy in 2008 irreversibly shifted the balance of economic power in favor of emerging economies, and the advanced countries continue to struggle with economic recovery. Consequently, active debates are underway regarding whether and how to adjust the existing aid architecture established by traditional donors after World War II to one based on the new Global Development Partnership, inclusive of new actor $\mathrm{s}^{1)}$.

Domestically, the positioning of Japan's ODA in the national policy has changed significantly. Until the early 1990s, ODA enjoyed strong political support in Japan, receiving a significant increase of annual budget allocation (See Box). As a result, by the beginning of the 1990s when the Cold War ended, Japan had become the world's largest donor in aid volume, surpassing the US. To assume global responsibility commensurate with its role as top donor, Japan made enormous efforts to contribute to international development by diversifying its priority regions and countries of ODA allocation beyond Asia, and by making active engagement in post-conflict nation building, global issues, and African development. The participation of the Peacekeeping

1) At the OECD/DAC Fourth High Level Forum on Aid Effectiveness in December 2011 (held in South Korea), the Busan Partnership for Effective Development Co-operation was agreed (OECD/DAC 2011). This is the framework for development cooperation agreed for the first time among traditional donors, South-South cooperators, emerging donors, civil society organizations, and private actors. Currently, the details of the working modalities are being discussed under the auspice of the DAC and the United Nations Development Programme (UNDP). More recently, at the request of the UN Secretary General, the High-Level Panel on Eminent Persons of the post-MDG Development Agenda compiled and submitted the report at the end of May 2013, calling for "A New Global Development Partnership" (UN 2013). 
Operations (PKO) in Cambodia in 1992 and the hosting of the Tokyo International Conference on African Development (TICAD) in 1993 were two good examples of Japan's strong resolve to making global contributions. The first ODA Charter was formulated in 1992.

It was unfortunate for Japan that this outward-looking period did not last for long. Following the bubble burst (1990-92) and the prolonged economic recession, the government was forced to take austerity measures, and the ODA budget was the item most severely hit. Japan's ODA budget, once regarded as sacred, has declined over the past 14 years with a cumulative reduction of 48 percent in FY2013 from the peak level in FY1997. As a result, on a net disbursement basis, the US replaced Japan as top donor in 2001 for the first time since 1991. Continuing its downward trend, Japan has been ranked fifth after the US, Germany, the United Kingdom (UK), and France since 2007²). Faced with fiscal austerity, the government and aid agencies were forced to strategically prioritize ODA spending in order to maintain aid effectiveness and respond to diversified global needs within the limited budget.

Yet, it is notable that the first decade of the $21^{\text {st }}$ century was the period when a series of ODA reforms were implemented in Japan. These include the revision of ODA Charter (in 2003), the formulation of the Medium-Term Policy on ODA (in 2005), and the new establishment of JICA (in 2008) through the merger of the ODA loan operations of the Japan Bank for International Cooperation (JBIC) ${ }^{3)}$ and the existing JICA, and so on. Also, such reforms were considered necessary for Japan to be able to participate effectively in aid partnership at the country-level, which was strongly demanded by the international aid community at that time.

2) Nevertheless, the government has maintained the size of ODA operations to meet the vast development needs of countries in Asia and other regions by actively mobilizing ODA loans. On a gross disbursement basis, Japan remains the second-largest donor among the OECD/DAC member countries.

3) JBIC was established in 1999, through the merger of the Overseas Economic Cooperation Fund (OECF) and the Export-Import (EXIM) Bank of Japan, as part of public financial sector reform. But, within ten years, again for the same reason, the OECF was separated from JBIC and merged with JICA. The OECF was established in 1961 as the executing agency of Japan's ODA loans. In 1962, JICA's predecessor, the Overseas Technical Cooperation Agency (OTCA) was created as the executing agency for technical cooperation. 


\section{Box: Past History of Japan's ODA}

Japan's postwar decision to renounce use of military force implied that foreign aid had to compensate for the lack of Japan's military contribution to conflict areas in the world. In fact, ODA has been Japan's principal means of participation in globally shared efforts and the main way of addressing Japan's specific external goals in each period, such as war reparation payment in the 1950s, trade promotion in the 1960s, securing imported energy and raw materials in the 1970s, and the "recycling" of the trade surplus in the 1980s. The end of the 1970s through the 1990s was the so-called "period of planned expansion" of ODA, during which the Japanese government set out successive medium-term targets and increased the amount of ODAit provided. As a result, by the beginning of the 1990s when the Cold War came to an end, Japan had become the world's top donor.

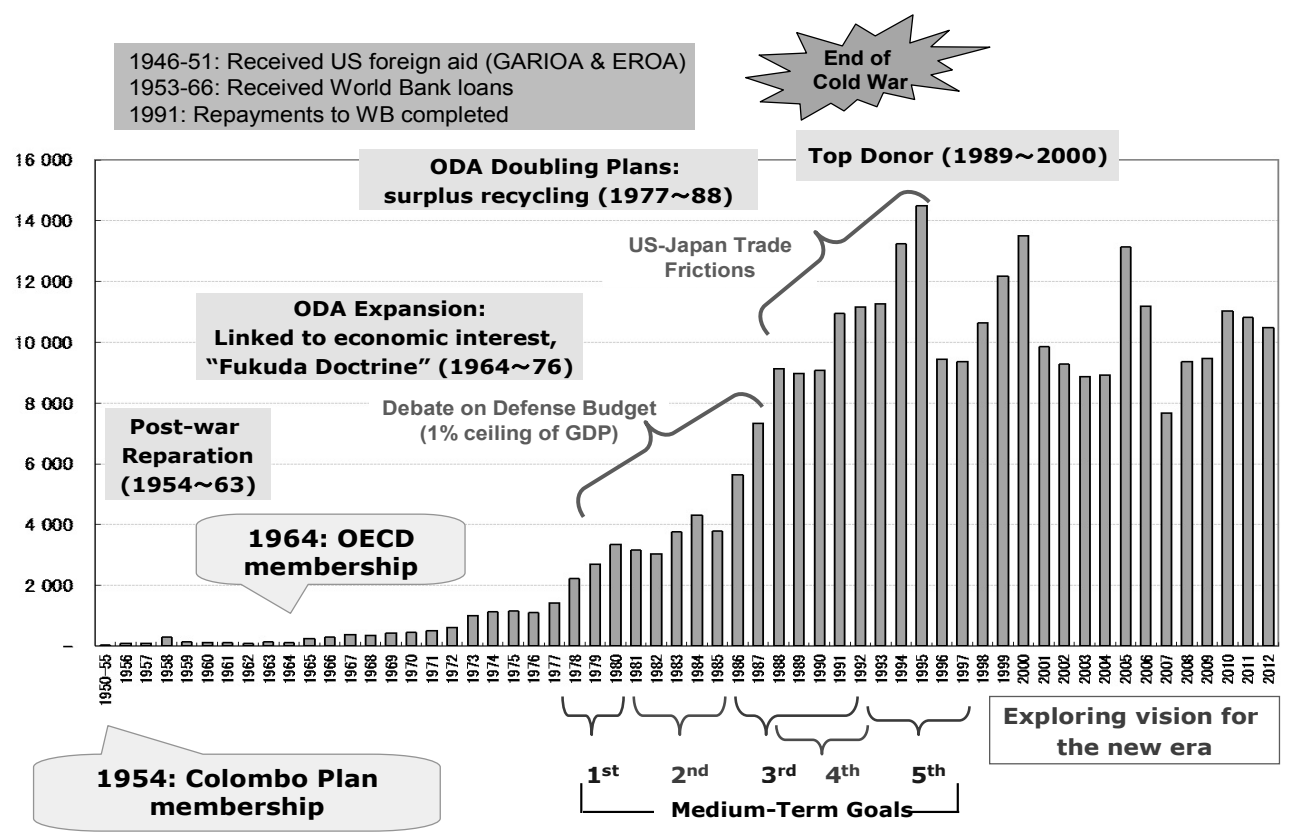

Note: A bar chart indicating the volume of Japan's ODA in net disbursements, indicated in US dollars. Source: Elaborated by the author, based on the information from the MOFA and the MOF. 
In the second decade of the 2000s, Japan faces further complex challenges. In March 2011, the Great East Japan Earthquake disaster hit the Pacific coast of the Tohoku region, causing enormous loss in human lives and property. In the coming years, the government must set aside a significant amount of the national budget to achieve early recovery and reconstruction in the disaster-struck region; therefore, fiscal austerity will continue. At the same time, the earthquake has provided an opportunity for Japanese citizens to appreciate the international cooperation offered from various countries, organizations, and individuals, and it has reminded us of the importance of inter-dependence and mutual help. The disaster was so devastating and painful that the whole nation united to support recovery and reconstruction of the Tohoku region. Alliances between businesses, NGOs and local communities were forged, and innovative activities are emerging, such as social business and social investment, to support the affected areas and people. Moreover, the Great East Japan Earthquake disrupted the global supply chain of manufacturing industries because of damage to factories in the Tohoku region. Together with the flooding in Thailand in October 2011, which again caused serious supply chain disruption of automobiles and electronics products in Japan and the world, Japanese citizens have become keenly aware of global connectivity and mutual dependence, and the importance of international cooperation.

\section{Policy and Institutional Reforms of Japan's ODA in the 1990s through the First Decade of the 2000s}

In the two and half decades of the 1990s through the early 2000s, a series of ODA reforms were carried out, driven by both external and domestic pressures, and the foundation of the present ODA policy and institutional framework was established.

Improving the ODA system and making a global commitment as top donor (1990s)

During the first half of the 1990s, Japan made explicit efforts to improve its ODA policy 
and institutional framework, to be commensurate with its position as top donor. On the policy framework, the government formulated the first ODA Charter in 1992 (approved by the Cabinet), and consecutively the Medium-Term Policy on ODA in 1999. These documents articulate the philosophy, principles and priority issues of Japan's ODA, as well as the approach and measures to ensure the efficient and effective implementation of assistance. The ODA Charter regards the support for self-help efforts of developing countries toward economic take-off as one of four principles, together with humanitarian assistance, inter-dependence, and environmental conservation (GoJ, 1992). Notably, the Medium-Term ODA Policy gives special consideration to South-South and triangular cooperation as an effective way to facilitate the transfer of technologies between countries at similar stages of development (MOFA, 1999). Given that this type of cooperation has recently been attracting attention among development actors, it should be stressed that Japan has long been at the forefront of such endeavors.

In the 1990s, Japan diversified the priority regions and countries and expanded the scope of assistance to respond to the evolving needs of the international community and to assume greater global responsibility as top donor (see Figure 1). The Persian Gulf War of 1991, waged by US-led UN-authorized multinational forces in response to Iraq's invasion and occupation of Kuwait, became a particularly major turning point. The Japanese government at that time made a pledge to contribute US $\$ 13$ billion to the cost of the war, but because the government took time to reach that decision, the assistance was not necessarily highly evaluated by the international community. The Gulf War experience was a big shock to the government and many Japanese citizens. Subsequently Japan made a policy shift to participate more actively in the tasks of preserving global peace and security, not only by providing financial support but also by contributing personnel. This has led to the establishment of the Law Concerning Cooperation for United Nations Peace Keeping Operations and Other Operations (PKO Law) and the start of dispatching of Self-Defense Forces personnel on PKO in 1992.

The first TICAD, held in October 1993 (in Tokyo), was Japan's major global initiative to promote high-level policy dialogue between African leaders and development 
partners. At this time, Western donors were losing interest in African development due to the aid fatigue that prevailed after the end of the Cold War. Since then, TICAD has been held at five-year intervals and become a major global framework to facilitate the implementation of initiatives for promoting African development under the dual principle of African "ownership" and international "partnership"4). Accordingly, regional and sectoral allocations of Japan's bilateral ODA have changed over time. Although Asia and economic infrastructure continue to enjoy high priority in Japan's aid, the shares of Africa and the Middle East regions have increased during the past 20 to 30 years (see Figure 2). Similarly, the share and the amount spent on social infrastructure services and humanitarian support have increased.

〈Figure 1〉 History of Japanese ODA Policy, Focusing on the Post-Cold War Era

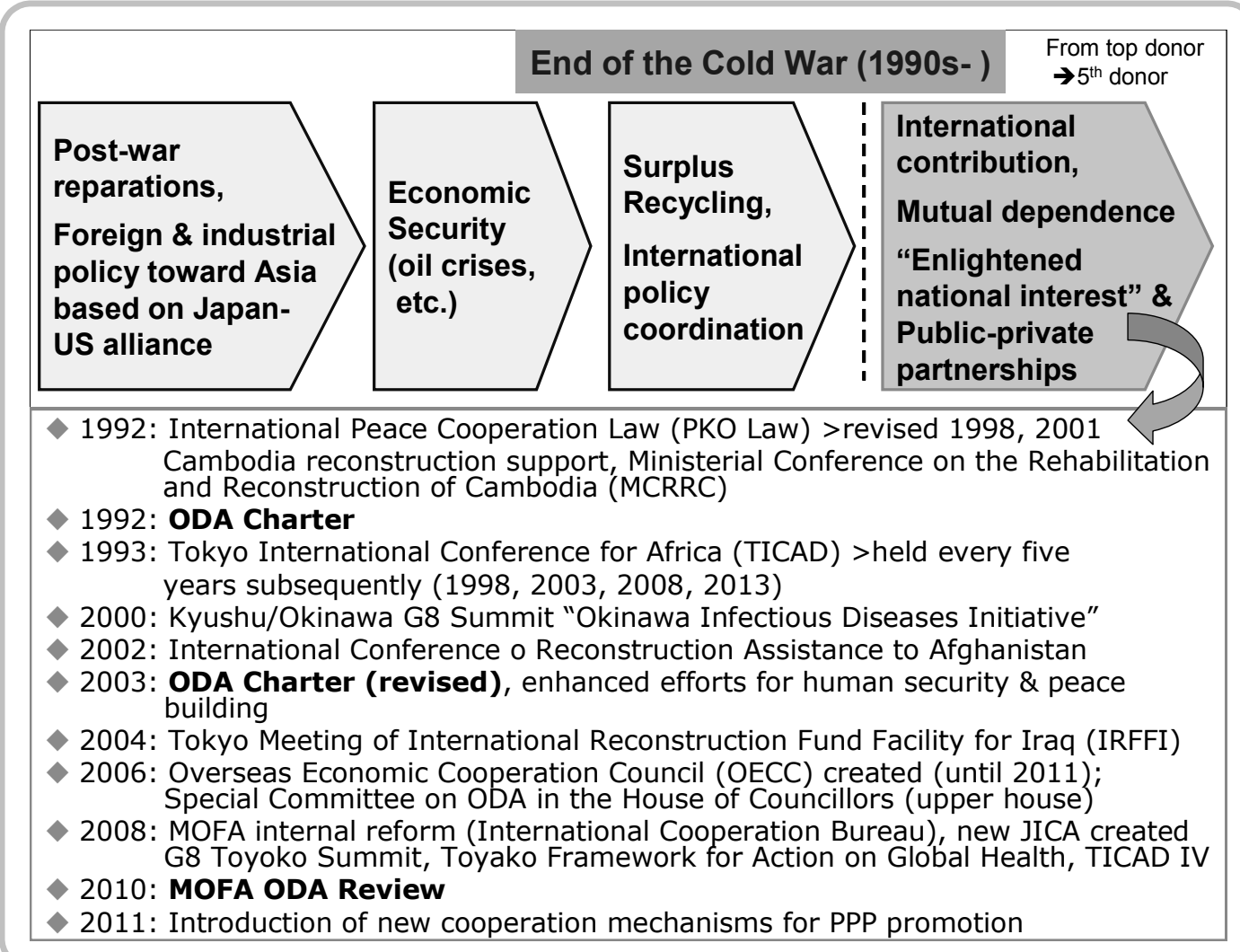

Source: Elaborated by the author.

4) See MOFA's TICAD homepage for details. http://www.mofa.go.jp/region/africa/ticad/what.html 
〈Figure 2〉 Regional Allocation of Japan's Bilateral ODA

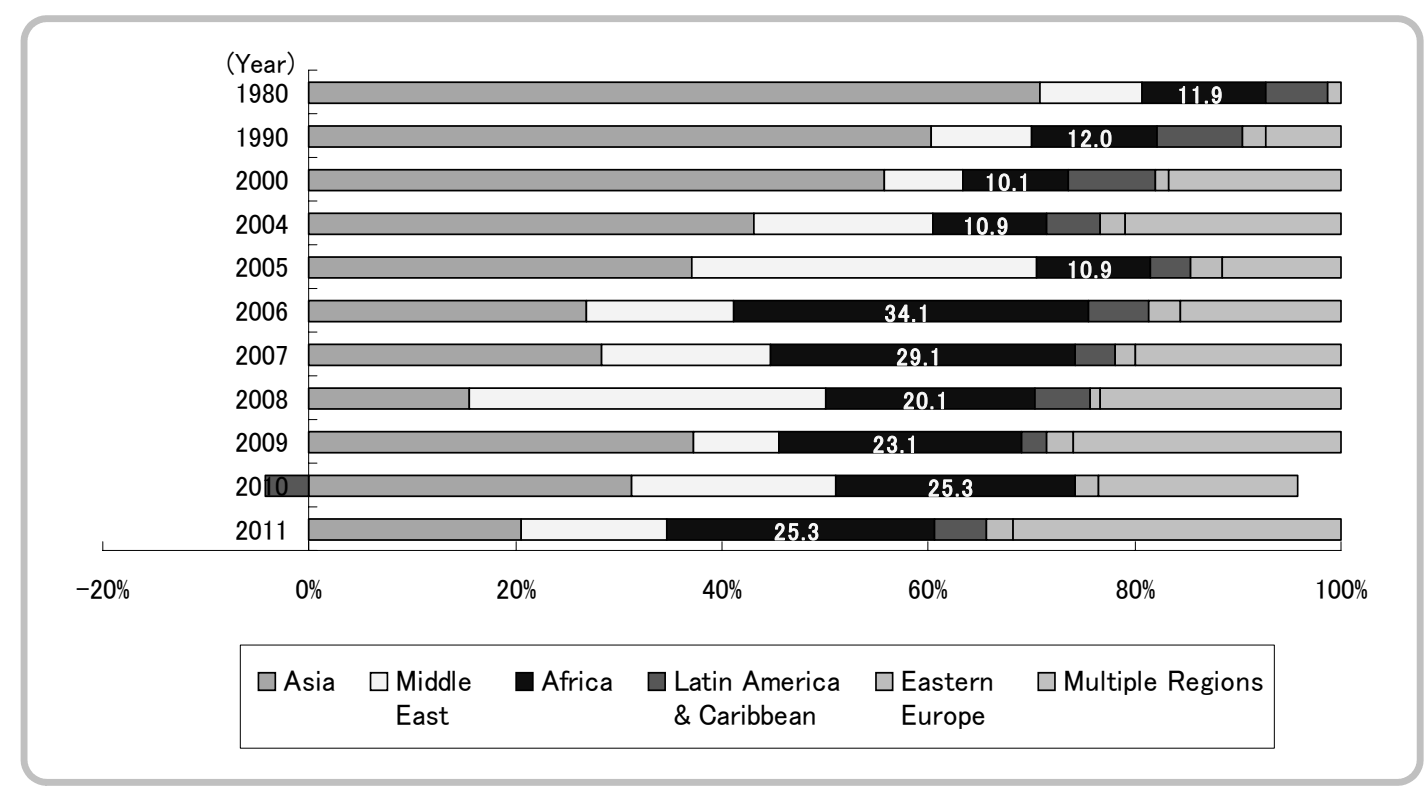

Note: Percentage is calculated on a net disbursement basis.

Source: Elaborated by the author, based on the data from the MOFA.

\section{Implementing ODA reforms under fiscal austerity and struggling to respond to global needs (first decade of the 2000s)}

The early 2000s was a difficult time for Japan's ODA. Under a prolonged recession, Japan's ODA budget experienced a deep cut in 2002 of more than 10 percent compared to the previous year. Popular support for ODA dropped sharply, as well. According to opinion polls conducted by the Cabinet Office5), during the period from 1991 to 2002, the share of those respondents who strongly supported Japan's engagement in economic cooperation ("should increase actively") declined from 41.4 percent to 19.2 percent, and those who were reluctant to support Japan's engagement ("should decrease" and "should stop”) increased from 9.3 percent to 29.1 percent (Cabinet Office of GoJ, 2012).

5) Every October, the Cabinet Office conducts opinion polls on foreign policy and publishes the results in April of the following year. Until 2011, the survey included questions related to economic cooperation. The number of respondents is approximately 2,000 , although the exact figure varies by year. 
Meanwhile, US and European donors were bolstering aid to a level unthinkable given their past stinginess, as poverty reduction was elevated to a high priority of the then-Bush administration's agenda to fight terrorism. Pressure on Japan to increase its ODA budget to accomplish the MDGs and to respond to various needs within the international community grew constantly. Moreover, there was strong pressure from Western donors to harmonize aid procedures, shift from project aid to budget support and promote decentralized decision-making by delegating the authority at the field-level. Japan fully recognizes the importance of aid coordination, alignment of donor support to the development priorities of partner countries and to their country systems (without creating parallel structures). At the same time, there are views among the Japanese development experts and practitioners that Western donors are often too idealistic about the functions of new aid modalities, such as budget support and pooled funds (against project aid), giving little consideration to the capacity of partner countries for fiduciary management and actual aid delivery on the ground (Ohno \& Niiya, 2004).

Such domestic and external pressures created a sense of urgency in the minds of Japanese development experts and officials, and the government initiated a series of ODA reforms starting in 2002. These include the revision of the ODA Charter, the establishment of country-based ODA Task Forces in major aid-recipient countries, the enhancement of country assistance programming, the implementation of systemic ODA evaluation, and so on. The ODA Task Forces primarily consist of the Japanese embassies and local offices of JICA, the Japan External Trade Organization (JETRO), and the JBIC. These are designed to strengthen the capacity for country-level aid programming and partnerships with other donors and related organizations.

The new ODA Charter (revised in 2003) defines the objective of Japan's ODA as "to contribute to the peace and development of the international community, and thereby to help ensure Japan's own security and prosperity." To this end, the charter establishes five basic policies: (i) supporting self-help efforts of developing countries; (ii) incorporating "human security" perspectives; (iii) assurance of fairness, giving consideration to vulnerable groups; (iv) utilizing Japan's experience and expertise; and 
(v) partnership and collaboration with the international community (GoJ, 2003). The Medium-Term Policy on ODA (revised in 2005) further elaborates the concept of "human security" and states that Japan will address the four priority issues of "poverty reduction," "sustainable growth," "addressing global issues" and "peace-building" described in the ODA Charter bearing in mind the perspective of "human security" in order to reduce the vulnerabilities faced by people, communities, and countries (MOFA, 2005). On this point, the intellectual leadership of Mrs. Sadako Ogata (former UN High Commissioner for Refugees, 1990-2000) was quite important6). Mrs. Ogata became the President of JICA in 2003 and took initiatives to strengthen JICA operations in Africa and post-conflict countries (such as Iraq and Afghanistan) and also to enhance the functioning of its field-offices.

The year 2006 and subsequent years saw further reforms involving restructuring of the institutional framework for ODA policy planning and implementation. At the strategy level, in April 2006, the Japanese government established the Overseas Economic Cooperation Council (OECC), which is chaired by the prime minister and includes the chief cabinet secretary, the Minister for Foreign Affairs, the Minister of Finance and the Minister of Economy, Trade and Industry among its members. (The OECC was abolished in October 2011 during the new Democratic Party of Japan [DPJ] administration.) At the policy level, the MOFA undertook internal reorganization in August 2006 by merging the bilateral and multilateral aid sections into one bureau, the International Cooperation Bureau (ICB). The ICB was further restructured in 2009, by transforming its scheme-based divisions (i.e., loans, grants and technical cooperation) into region-based ones. It is also important to note that a special committee for ODA was created in the House of Councilors (the upper house) in January 2006. This implies that the channel of politicians' participation in ODA policy had expanded7).

6) In 2001, the Commission on Human Security, chaired by Nobel Laureate Amartya Sen and the former UN High Commissioner for Refugees Sadako Ogata, was established to concretize the concept of human security and to make recommendations for policy to the UN Secretary General.

7) Nevertheless, it should be noted that the upper house is primarily responsible for spending review, not for budget formulation. 


\section{ODA Charter}

\section{Medium-Term ODA Policy}

\section{Country Assistance Policy}

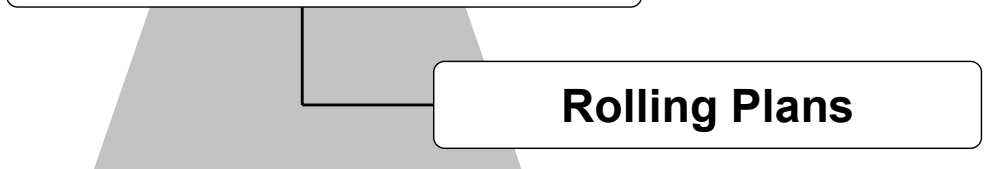

\section{Sectoral Development Policy}

\section{Priority Policy Issues for International Cooperation}

Source: Japan's ODA White Paper 2012, MOFA (2013)

At the implementation level, the new JICA was established in October 2008, through the integration of ODA loan operations (which were under the JBIC until September 2008) and part of grant aid (under the MOFA) into the JICA ${ }^{8)}$. The new JICA became operational in October 2008. It is effectively the world's largest bilateral development agency, and, overall, second only to the World Bank. With annual gross disbursements at around US $\$ 12 \mathrm{bn}^{9)}$, the new JICA is a unique aid agency providing technical cooperation, grant aid and ODA loans in an integrated manner. It is the expectation that a single ODA-executing agency should lead to stronger linkages among various

8) The creation of the new JICA was a by-product of the reform of public financial institutions, rather than the outcome of ODA reform. The reform of public financial institutions derived from ex-Prime Minister Koizumi's resolve to downsize the administrative apparatus. The treatment of JBIC, a public financial institution charged with international finance operations, triggered fierce debates on the appropriateness of the existing ODA system and resulted in the birth of the new JICA.

9) The size of JICA operations in gross disbursements (technical cooperation, grants and ODA loans) was JPY 1,174 billion in FY2012, on the basis of the JICA annual report. 
aid instruments and reinforce country approaches with greater field delegation. Moreover, since 2011, private sector investment finance (PSIF) has been added to JICA's menu. This instrument is to provide loans and equity investments to private companies and special purpose companies for the implementation of projects that contribute to the economic development of developing countries.

Figures $3 \& 4$ show the present policy and institutional framework for Japan's ODA.

〈Figure 4〉 Institutional Framework for Japan's ODA

\section{Issue-specific policy committees}

※ Overseas Economic Cooperation Council (established in April 2006) was abolished in Oct. 2011. ※ While there is no government-wide committee specialized in ODA or economic cooperation, this matter is discussed as part of issue-specific national policy committees (e.g., overseas infrastructure development, SME business promotion).

\section{Strengthening of MOFA's policy planning and coordination capacity}

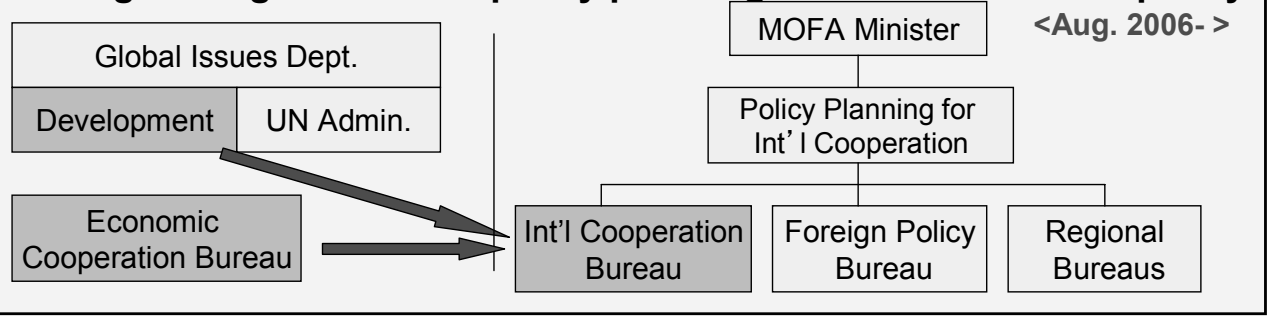

3. New JICA with multiple aid menu

<Oct. 2008- >

JBIC

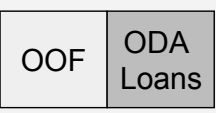

JICA

TA
MOFA

Grants
New PFI

\begin{tabular}{|c|c|c|c|}
$\begin{array}{c}\text { Public Financial } \\
\text { Institutions }\end{array}$ & OOF \\
\hline
\end{tabular}

New JICA

ODA Loans 


\section{Getting ready for the new era?: From ODA to development cooperation (second decade of the 2000s)}

In September 2009, the DPJ assumed power after the long rule of the Liberal Democratic Party (LDP). Instructed by then-new Foreign Minister Katsuya Okada, the MOFA undertook an internal ODA Review and compiled a final report entitled, "Enhancing Enlightened National Interest: Living in harmony with the world and promoting peace and prosperity" in June 2010 (MOFA, 2010). The report deserves attention for several reasons. First, it proposed the concept of "development cooperation," which includes not only ODA but also other official flows (OOF) and cooperation by non-pubic sectors (private companies, NGOs, citizens), based on the fact that more diverse players are getting deeply involved in development. Second, it proclaimed "the promotion of enlightened national interest," recognizing today's interdependent world. Third, it proposed a number of concrete measures to promote public understanding and support for ODA and to improve its strategic value and effectiveness in a changing global environment. Fourth, it recommended that the MOFA start discussions in the government towards the revision of the ODA Charter to reflect the new international and domestic environments and the policy direction of this ODA Review.

Many of the suggested measures in the third point above were implemented by the government and JICA, such as strengthening cooperation with NGOs and private business, reforming aid schemes (e.g., as the introduction of ODA loans in foreign currency, JICA's PSIF), increasing the independence of the ODA evaluation office within the MOFA, improving the information disclosure on ODA projects, and so on. However, the revision of the ODA Charter has not been followed up. In the subsequent years of the DPJ administration, national debates tended to narrowly focus on administrative and domestic affairs rather than on Japan's future vision in an increasingly connected world. A typical example is the budget screening and transparency campaign (jigyou shiwake) launched in November 2009, under which the ODA budget was put under severe public scrutiny. 
In late December 2012, the LDP regained control of the government by winning a clear majority in the national election. Under the LDP administration led by Prime Minister Shinzo Abe, the government increasingly regards ODA as one of Japan's key diplomatic tools. The MOFA's priority policy issues for international cooperation for FY2013 state that ODA is to be utilized strategically and effectively under three major objectives: (i) to realize a prosperous, free and stable international community; (ii) to support the growth of emerging and developing economies together with the growth of the Japanese economy; and (iii) to promote human security and strengthen trust in Japan ${ }^{10)}$. Although these elements were already noticeable to some extent under the previous administration, it appears that (i) and (ii) are being pushed more forcefully. Emphasis is placed on enhancing the quality and impact of ODA through improving partnerships with diverse players outside the government and the JICA, such as NGOs, small-and medium-enterprises (SMEs) and other private companies, local governments and universities, by involving their advanced technologies and know-how in overall ODA activities. Since around 2011, the MOFA and the JICA have introduced new cooperation modalities to promote public-private partnerships (PPP) such as preparatory surveys for PPP infrastructure projects and Base of the Pyramid (BOP) business ${ }^{11)}$, PSIF, and more recently, those to promote partnerships with Japanese SMEs interested in contributing to the socio-economic development of developing countries, utilizing their technologies. If effectively implemented, such cooperation modalities can be useful for Japan to build continued partnerships with middle-income countries to address their socio-economic challenges, even after they have graduated from aid.

Also, regarding (iii), Japan wishes to contribute to the solution of common global issues -in particular, disaster prevention and management-by sharing with the international community its accumulated experiences and knowledge of overcoming natural disasters. Although Japan has long been actively helping disaster-stricken countries, the

10) See MOFA's homepage on Japan's ODA http://www.mofa.go.jp/policy/oda/oda_policy/pdfs/priority_policy_13.pdf

11) BOP businesses, often called "inclusive business," is a private-sector approach to providing goods, services, and livelihoods on a commercially viable basis to people at the base of the pyramid by making them part of the value chain of companies' core business as suppliers, distributors, retailers, or customers. 
government and citizens feel strongly that it should assume unique global responsibility for sharing its own experiences and knowledge obtained from the reconstruction process of the Great East Japan Earthquake ${ }^{12)}$.

The above direction can be also confirmed from the outcome of the TICAD V, held in Yokohama in June 2013. Embracing the concept of "Hand in Hand with a More Dynamic Africa," the Japanese government announced its basic policy for supporting African development through two pillars: (i) boosting the growth of Africa through trade and investment of the private sector; and (ii) promoting human security through Japan's unique assistance. To this end, Japan plans to contribute to the growth of Africa, utilizing private and public means of up to approximately JPY 3.2 trillion (equivalent to US $\$ 32$ million), including ODA of approximately JPY 1.4 trillion (equivalent to US $\$ 14$ billion), in the next five years ${ }^{13)}$.

Although Japan continues to face fiscal stringency, it appears that the pace of ODA budget cust has stabilized in recent years. The budget reduction was 0.7 percent in FY2013, compared to 7.4 percent in FY2011 and 2.0 percent in FY2012. Among them, the MOFA's ODA (which accounts for about 75 percent of the total) slightly increased for three consecutive years (by 0.7 percent in FY2013). The JICA budget also increased by 1.1 percent in FY2013. Certainly, the Great East Japan Earthquake has significantly affected citizens' thinking. The recent opinion polls show that after hitting the bottom in the early 2000s, the percentage of citizens who support the idea of ODA has recovered to 31.5 percent (in 2010) and 27.4 percent (in 2011). In the October 2011 survey, those who answered positively think Japan should extend cooperation to respond to the support from various countries after the Earthquake (60.8 percent); economic cooperation is an important diplomatic tool (50.3 percent); and Japan should utilize its experience and technology for global issues faced by developing countries (49.6 percent) (Cabinet Office of GoJ, 2012).

12) In this regard, Japan will host the United Nations World Conference on Disaster Reduction in Sendai City, Miyagi-Prefecture in March 2015. The conference will discuss a post-2015 framework on disaster risk reduction, building on the current Hyogo Framework for Action 2005-2015.

13) For more details of the outline of Japan's assistance package for Africa at TICAD V, see: http://www.mofa.go.jp/files/000005505.pdf 
The current government has not yet clarified its position on the revision of the 2003 ODA Charter. I believe that the time is ripe for the MOFA to initiate discussions on this matter, given the significant changes in the external and domestic environment of Japan's ODA over the last ten years. There is a need for Japan to reaffirm its rationale for and commitment to international development and get ready to make its unique contributions to the new era of development cooperation.

\section{Toward a New Era of Development Cooperation: The Role of Japan in Supporting Country-Specific Growth Strategies, Based on East Asian Perspectives 14)}

As discussed in the previous sections, Japan has advanced a series of ODA reforms over the past years, and global development debates are now shifting toward sustainable and inclusive growth, with deeper partnerships with the business sector. Japan should take this opportunity to make unique contributions to shaping international development policy for the new era. It should bring East Asian perspectives together with new actors in a way that reflects Japan's dual experiences as latecomer and donor. Regarding partnership with emerging donors, Japan has been at the forefront of South-South and triangular cooperation even before the $21^{\text {st }}$ century.

The following section will outline what I believe to be key elements of Japan's unique contributions, particularly in the area of supporting country-specific growth strategies. Japan's development and aid visions and its growth support approach will be discussed, with specific reference to the ongoing Japan-Ethiopia industrial policy dialogue jointly supported by JICA and GRIPS.

14) This section is adapted from Izumi Ohno \& Kenichi Ohno, "Eastern and Western Ideas for African Growth," World Financial Review, pp. 40-44, July/August issue, 2013 (@EBR Media Ltd. 2013), and Izumi Ohno (2013). 


\section{Japan's development and aid visions: How do they differ from the Western approach?}

Japan's development and aid visions strongly reflect its dual experience as a latecomer and a donor. First, Japan is the only non-Western country with an early history of successful industrialization. Ever since Japan opened its doors to the world in the second half of the nineteenth century, the desire to catch up with the advanced nations in the West has been a strong driving force leading to its economic achievements today. Second, the generation of Japanese who lived through it vividly remembers the destruction and poverty the nation sustained following its defeat in World War II. This situation was gradually overcome by very hard work, a fact in which that generation still takes considerable pride. Japan's success in strengthening its manufacturing base in turn contributed to trade- and investment-driven development and resultant poverty reduction in East Asia. Thus, the East Asian experience and aspiration for industrial catch-up are at the heart of Japan's ODA vision. Being a late industrializer, Japan possesses a unique dual identity as a member of developing Asia as well as a member of the developed West.

These historic factors have heavily influenced the shaping of development visions and relationships Japan wished to foster with developing countries through aid. There exist notable differences among donors and their approaches to aid and development. East Asia, including Japan, is interested in achieving concrete results and projects rather than formal correctness, prioritizing a few sectors for industrialization, and eventual graduation from aid. By contrast, Western donors emphasize good governance and an early adoption of policies and institutions that copy international best practices. For example, the Doing Business Indicators ${ }^{15)}$ and the Worldwide Governance Indicators $(\mathrm{WGI})^{16)}$ extract desirable attributes of growth-friendly governments from the advanced

15) Since 2004, the World Bank and the International Finance Corporation (IFC) have published Doing Business reports annually (World Bank \& IFC, 2004). The reports track regulatory reforms aimed at improving the ease of doing business and include country rankings. The 2013 report covers 185 economies, including top three reformers Singapore, Hong Kong, and New Zealand. South Korea, Japan, and China score $8^{\text {th }}, 24^{\text {th }}$, and $91^{\text {st }}$ respectively.

16) WGl have been published annually since 1996, quantifying the six dimensions of governance in 
West and evaluate and rank developing countries by these criteria. While Growth Diagnostics devised by Harvard professors (Hausmann, Rodrik, \& Velasco, 2005) is a major departure from the long and universal policy menu of the Washington Consensus by focusing on a few binding constraints to growth, its logic tree tries to identify weaknesses of developing countries in terms of international standards and tries to remove them with limited attention to political feasibility.

As discussed below, the East Asian approach is characterized by real-sector pragmatism, goal orientation, and the pursuit of unique strengths of a particular country. The problem of weak policy capability is overcome through focused hands-on endeavors to achieve concrete objectives, rather than trying to improve governance scores generally vis-à-vis the global standard with no specific goals. We call this approach "dynamic capacity development" (Ohno 2013, Ohno \& Ohno 2012). Dynamic capacity development aims at improving policy capability through acquiring knowledge and skills by solving specific problems while working toward achieving concrete goals. This approach should help developing countries gain confidence by step by step.

\section{Real-sector pragmatism}

Yanagihara (1998) distinguishes the "framework approach" practiced by Western aid donors and the "ingredients approach" adopted by the Japanese government in its development aid strategy. The framework approach emphasizes the rules of the game according to which the private sector acts and policy makers make decisions while leaving the actual outcome of the game to individual matches and players. In this approach, the functioning of markets, the principle of official intervention, budget and public investment frameworks, empowerment and participation, monitoring mechanisms,

countries around the world and compiling data for cross-national comparison. Like Doing Business rankings, WGl serve as useful benchmarks to help understand the relative level of governance of a particular country and institutional reforms required for its development. But, these indicators tend to suggest comprehensive reforms that may not be implemented by developing countries with scarce resources (see Ohno \& Ohno 2012). 
administrative efficiency and accountability, and the like, receive great attention. Aid harmonization and general budget support are clearly couched in this tradition. In contrast, the ingredients approach takes a deep interest in how individual players are doing in the field and the outcome of each game. It examines the state of technology, factors of production, demand trends, product mixes, industrial structure, marketing and logistic efficiency and the like, in the concrete context of individual sectors and regions of the country in question. Matching crop species with particular soil or training factory inspectors for kaizen (quality improvement guidance at the production floor)17) and efficient use of equipment are considered crucial for successful development. Similarly, the technical specification of roads and bridges to be built, the lot size and administrative supports in an industrial zone, and other details which are normally left to consultants and contractors are the proper concern of Japanese aid officials.

\section{Goal orientation}

In high performing economies in East Asia, industrial policy has usually taken a goal-targeting form: The top government leader proclaims a long-term national vision that shows a direction without specifying details. To realize this vision, appropriate government organizations are created or designated to draft ambitious but feasible strategies and execute concrete action plans. Strategies and action plans may be revised as circumstances change, but the long-term vision remains intact. Working backwards from broad goals to phased strategies and concrete action plans, while making necessary adjustments and accumulating experience and confidence along the way, has been the hallmark of East Asian development planning.

Japan in the 1960s had the goal of doubling income within the decade as well as competing effectively with Western multinationals as trade barriers were lifted under the Kennedy Round commitments of the General Agreement on Tariffs and Trade (GATT). The Ministry of International Trade and Industry (MITI) together with the

17) Kaizen, in Japanese management, means "continuous improvement" of productivity and quality without additional cost in a participatory process with a bottom-up approach. 
Japan Development Bank coordinated and assisted private efforts in improving productivity. Taiwan in the 1980s launched high-tech industry promotion to replace the heavy industry drive of the 1970s. Priority areas were designated, a science and technology industrial park was created in Hsinchu, foreign direct investment (FDI) marketing was conducted, and measures were introduced to support research and development (R\&D) and financing of eligible companies.

\section{Enhancing unique strengths rather than removing general negatives}

Instead of comparing countries across the board to rank them or find faults with individual countries relative to the global norm, the East Asian approach is to identify the future potential (dynamic comparative advantage) unique to each country. Limited resources are poured into this area to realize that potential rather than scattered across many unrelated programs. The development strategy of a land-locked country with rich mineral resources should be entirely different from that of a country with long coastal lines and excellent seaports. Unique potential for each country should be identified, and main policy efforts must be directed toward removing barriers to attain that potential.

Consequently, in providing development assistance, Japanese experts pay attention to the strengths of a country and consider how to make full use of the country's economic potential. Particular bottlenecks are identified in this light (such as infrastructure, human resources, technology, specific institutional capacity), and goals and targets are set to remove the bottlenecks. Concrete targets, such as construction of a trunk road from $A$ to $B$ or promotion of certain industry by a certain deadline, are preferred over general improvements in governance or private sector capability. Then plans and actions are created backwards, thinking from the future to the present, to attain certain goals and targets. This is in sharp contrast to the call for wide-ranging reforms without specific real-sector targets such as those of IMF conditionalities, World Bank policy matrices, good governance drive, and other institutional reform agenda. 


\section{Comprehensive policy dialogue as an entry point for country-specific growth support}

Then, how should the East Asian approach be practiced in a latecomer country, for example, an African country? We believe that policy dialogue, which Japan has conducted routinely in East Asia, can be a valid instrument for supporting African growth. Since the East Asian approach rejects the idea of common answers, it cannot deliver a pre-determined solution applicable to all countries. The lessons must be learned interactively. What this approach can offer is a suggestion for methodologythe way a solution should be constructed for each country.

Policy dialogue is intellectual cooperation between a developing country and an advanced one, held regularly over several years with an open and evolving agenda. There is no pre-determined formula for cooperation, and responsiveness to clients' needs and "think-together" approach drive the dialogue process. Policy dialogue differs from technical assistance with narrowly prescribed terms of reference or with a standardized policy matrix. It is also unlike seminars and tours organized by an industrialized country to publicize its past achievements. Japan's policy dialogue cites concrete cases from all around the world-not just Japanese experiences, which are usually too advanced for many developing countries. If strong ownership and commitment exist on the side of the partner countries, they should serve as a useful instrument for helping improving their policy capability through hands-on advice.

Starting with Argentina, Japan has conducted policy dialogue with many developing countries in various modalities regarding purpose, scale, participants, duration, and frequency (see Table 1). It usually starts with a national leader of a developing country requesting that Japan discuss general development strategy or teach and transfer the experiences of East Asian development. In countries such as Vietnam, Indonesia and Laos, the Japanese government has mobilized a large number of academics, businesses, and aid consultants to identify key issues, study them, and offer policy advice. A similar policy dialogue is about to start in Myanmar. 
While East Asia and Sub-Saharan Africa are different and issues and solutions may differ considerably between the two regions, the method of organizing policy dialogue as discussed above should be valid for any latecomers. Admittedly, Japan has a far smaller presence in FDI and ODA in Sub-Saharan Africa than in East Asia, where its economic ties and aid efforts are concentrated. For this reason, Japan's growth assistance initiative in Sub-Saharan Africa should start with a manageable size and initially target only one or two countries that are willing and able to learn (GRIPS Development Forum, 2008b). In the chosen country, Japan should become a lead donor in growth policy and work closely with other stakeholders such as domestic and foreign businesses, academics, NGOs, and bilateral and multilateral donors.

\section{〈Table 1〉 Japan's Policy Dialogue with Developing Countries}

\begin{tabular}{|c|c|c|c|}
\hline Country & Period & Head/key players & Purpose and content \\
\hline Argentina & $\begin{array}{l}1985-1987 \\
1994-1996 \\
\text { (follow up) }\end{array}$ & $\begin{array}{l}\text { Saburo Okita (former foreign } \\
\text { minister) }\end{array}$ & $\begin{array}{l}\text { Comperehesive study on agriculture and livestock farming, } \\
\text { industry, transport and export promotion }\end{array}$ \\
\hline Thailand & 1999 & $\begin{array}{l}\text { Shiro Mizutani (former MITI } \\
\text { official) }\end{array}$ & Study on the master plan for SME promotion policy \\
\hline Vietnam & $1995-2001$ & Shigeru Ishikawa (professor) & $\begin{array}{l}\text { Large-scale joint study on macroeconomy, industry, } \\
\text { agriculture, enterprise reform, crisis management, etc. }\end{array}$ \\
\hline Vietnam & 2003-current & $\begin{array}{l}\text { Japanese embassy, JICA, } \\
\text { JETRO, JBIC }\end{array}$ & $\begin{array}{l}\text { Bilateral joint initiative to improve business environment and } \\
\text { strengthen competitiveness through } 2 \text {-year cycle of action plans }\end{array}$ \\
\hline Indonesia & 2000 & Shujiro Urata (professor) & Policy recommendation for SME promotion \\
\hline Indonesia & $2002-2004$ & $\begin{array}{l}\text { Takashi Shiraishi and Shinji } \\
\text { Asanuma (professors) }\end{array}$ & $\begin{array}{l}\text { Policy support for macroeconomic management, financial } \\
\text { sector reform, SME promotion, private investment promotion, } \\
\text { democratization, decentralization and human resource } \\
\text { development }\end{array}$ \\
\hline Laos & $2000-2005$ & Yonosuke Hara (professor) & $\begin{array}{l}\text { Study on macroeconomy, finance, state enterprise, FDI and } \\
\text { poverty reduction, etc. }\end{array}$ \\
\hline Myanmar & 1999-2002 & Konosuke Odaka (professor) & $\begin{array}{l}\text { Study on agriculture, rural development, industry, trade, } \\
\text { finance, ITC, etc. }\end{array}$ \\
\hline Mongolia & $1998-2001$ & $\begin{array}{l}\text { Hiroshi Ueno and Hideo } \\
\text { Hashimoto (World Bank } \\
\text { economists and professors) }\end{array}$ & Study on the support for economic transition and development \\
\hline Vietnam & $2008-2010$ & $\begin{array}{l}\text { Japanese embassy, JICA, } \\
\text { JETRO, businesses, } \\
\text { GRIPS/VDF }\end{array}$ & $\begin{array}{l}\text { Produce supporting industry development action plan for joint } \\
\text { implementation }\end{array}$ \\
\hline Ethiopia & 2009- & $\begin{array}{l}\text { GRIPS Development Forum } \\
\text { and JICA }\end{array}$ & $\begin{array}{l}\text { Kaizen, basic metals \& engineering, productivity movement, } \\
\text { policy procedure \& organization, export promotion, etc. }\end{array}$ \\
\hline Vietnam & $2011-$ & $\begin{array}{l}\text { Japanese embassy, JICA, } \\
\text { JETRO, METI, GRIPS/VDF }\end{array}$ & $\begin{array}{l}\text { Select and intensively promote a small number of indutrial } \\
\text { sectors; draft and implement detailed action plans }\end{array}$ \\
\hline
\end{tabular}

Source: Author's research.

Note: This table lists policy dialogues that are large-scale or worthy of special attention. Besides these, Japan offers policy advice through dispatching advisors to heads of state or ministers, expert dispatches, drafting reports on development strategy, training courses and site visits, conferences and seminars, etc. in various scale and duration.

Abbreviations: MITI (Ministry of International Trade and Industry), SME (small and medium enterprises), JICA (Japan International Cooperation Agency), JETRO (Japan External Trade Organization), JBIC (Japan Bank for International Cooperation), GRIPS (National Graduate Institute for Policy Studies). 
Western donors and international organizations also conduct "policy dialogue," but their topics tend to be less industrial and more towards the macroeconomic, legal, social or governance aspects. When industrial issues are taken up, they are usually cross-sectoral problems such as information and communication technology (ICT), globalization, green growth, and enterprise reform rather than sector-specific targeting or planning. Japan's policy dialogue is unique in the sense that it aims at directly strengthening the state's role and capacity for industrialization rather than reducing the scope of government intervention. Korea also offers large-scale policy cooperation to developing countries in its Knowledge Sharing Program (by the Korean Development Institute [KDI]) and the Consultation Program based on the Korean Development Model (by the Korea International Cooperation Agency [KOICA]); however, the Korean approach is far broader and more standardized than the Japanese one.

\section{Example: Japan-Ethiopia industrial policy dialogue}

The Japan-Ethiopia industrial policy dialogue is a pioneer example of the endeavor to transfer the East Asian development approach to Africa. This intellectual cooperation was launched upon a request from late Prime Minister of Ethiopia, H.E. Mr. Meles Zenawi, who had strong interest in the experiences of East Asian industrial development. What triggered the late Prime Minister's request was a report compiled by Japanese researchers (GRIPS Development Forum, 2008a) ${ }^{18)}$, which highlights the JICA's kaizen project in Tunisia in comparison with European Union (EU) assistance for firms to acquire the International Organization for Standardization (ISO) certificate. Both projects aimed at strengthening Tunisia's industrial competitiveness through quality improvement. But, the JICA project took an order-made approach, providing firm-specific diagnosis and guidance to 28 model firms, while the EU project took a ready-made approach based on international standards like ISO. Subsequently, he requested that the Japanese government provide intellectual support to Ethiopia's

18) See, Kikuchi Tuyoshi (2013). This paper particularly attracted the attention of late Ethiopian Prime Minister Meles Zenawi, leading to a request for Japan's kaizen assistance to Ethiopia. The earlier version was published in GRIPS Development Forum (2008a). 
industrial development strategy from an East Asian perspective through policy dialogue and technical cooperation for a kaizen project.

Since 2009, JICA has started industrial development cooperation with Ethiopia, consisting of two programs: (i) industrial policy dialogue with the GRIPS research team; and (ii) a kaizen project carried out by a team of Japanese consultants (see Figure 5). In the first-phase industrial policy dialogue (2009-2011), the JICA-GRIPS team visited Ethiopia every three months and conducted policy dialogue, mainly through three channels: (i) direct dialogues with the prime minister; (ii) meetings and discussions with senior policy makers such as the senior economic advisor to the prime minister, the ministers and the state ministers of the relevant ministries (High Level Forum); and (iii) meetings, discussions, and collaborative work with the policy makers and practitioners in charge ${ }^{19)}$. At the request of the Ethiopian government, the project has been extended, and currently the second-phase industrial policy dialogue (20122015) is being implemented under new Prime Minister H. E. Mr. Hailemariam Desalegn, who assumed the office in September 2012. The second phase of the kaizen project also got underway from late 2011 to support the newly established Ethiopia Kaizen Institute (EKI), which is the first public institution to include "kaizen" in its name.

Ethiopia stands out from other countries in Africa because its Industrial Development Strategy (formulated in 2002) has a clear policy orientation and the government has been taking promotional measures for selective, priority industries. The Ethiopian government is keen to benefit from East Asian industrial development experience-not only the content, but also the specific and action-oriented formulation of policies and organizational arrangements. Through the joint work and open dialogue process, this bilateral industrial policy dialogue aims to nurture mutual understanding on the progress and bottlenecks of Ethiopian industrial development, as well as explore future courses of action to be taken. Topics discussed during 2009-2011 included the next five-year development plan, called the Growth and Transformation Plan (GTP)

19) For the details of the Japan-Ethiopia industrial policy dialogue, see the first-phase report, Intellectual Partnership for Africa: Industrial Policy Dialogue between Japan and Ethiopia, compiled by JICA and GRIPS Development Forum, December 2011. 
(focusing particularly on issues related to industrial development), the methods for drafting industrial master plans and action plans, organizational aspects of industrial policy formulation, basic metal and engineering industries, and the concept and practice of kaizen. Concrete industrial projects and studies were proposed and agreed upon as a result of policy dialogue at high levels. This type of process has facilitated the identification of JICA's prospective projects in Ethiopia, as well.

\section{〈Figure 5〉 JICA-GRIPS Industrial Policy Dialogue with Ethiopia}

\section{Industrial policy dialogue}

Preparation

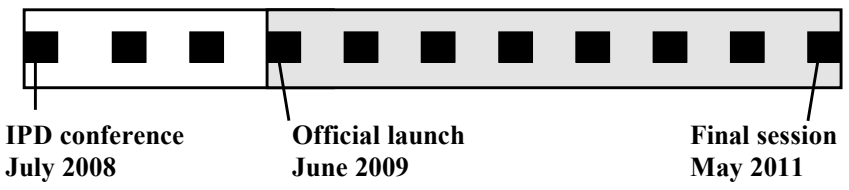

PM Meles
Phase 2

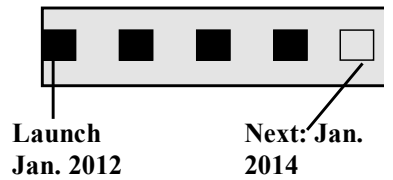

PM Hailemariam
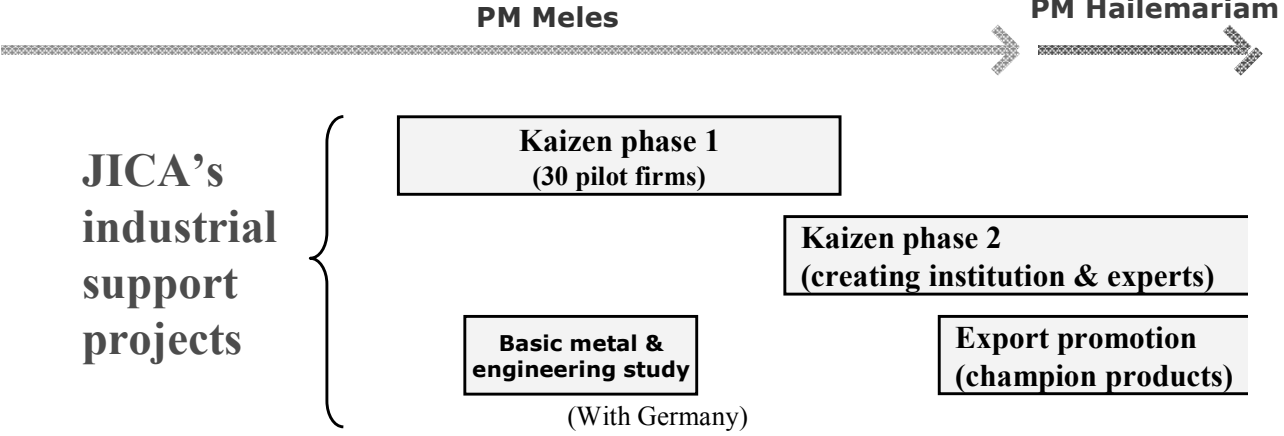

Note: Black squares indicate policy dialogue sessions in Addis Ababa with the prime minister, concerned ministers and state ministers, and officials and experts at operational levels.

Source: Elaborated by the author.

In the second-phase industrial policy dialogue, we have so far discussed such topics as strategic approaches to export promotion and FDI attraction, as well as technology transfer by promoting local and foreign business linkages. These are essential elements of the effective implementation of the five-year development plan (GTP) and have been strongly requested by the Ethiopian senior policymakers for learning the practices of the East Asian countries. A distinctive feature of the second-phase activity is that the dialogue process is combined with South-South and triangular cooperation in 
partnership with third-country experts and institutions. In our recent dialogues that focused on export promotion and FDI attraction, JICA invited experts and practitioners from Malaysia and Thailand who are responsible for trade promotion and FDI attraction in the government and related organizations to share their past and current practices and lessons in details. Furthermore, JICA organized a joint mission to Malaysia, consisting of the Ethiopian delegation (led by the State Minister of Industry and including eleven officials from various ministries and agencies) and the Japanese team (JICA and GRIPS), to study Malaysia's experiences in industrialization and draw implications for Ethiopia. In this way, Japan's policy dialogue is not just about sharing Japanese development experiences. It collects and introduces international best practices from Asia (and the other regions as necessary), and conducts in-depth discussions on their implications for Ethiopia from comparative perspectives.

\section{Conclusion}

Over the past decade, a number of emerging economies have become important players in South-South cooperation, and private actors are increasingly engaged in businesses that have important impacts on development. The second decade of the $21^{\text {st }}$ century is a critical period for establishing global partnerships for effective development cooperation (OECD/DAC, 2011) and shaping the post-MDG framework for development in an inclusive manner with the broader development actors. Japan has been practicing South-South and triangular cooperation even before the $21^{\text {st }}$ century. Moreover, close linkages among aid, trade and investment have been a key feature of Japan's ODA and development cooperation. In this context, Japan's approach to supporting country-specific growth strategies, with the East Asian perspectives of real-sector pragmatism and goal orientation based on unique strengths, can be useful complements to the Western approach. Such an approach should "offer a wider set of options from which developing countries can choose and combine” (Menocal \& Denny, 2011).

There are good opportunities for Japan, with its distinctive strengths, to add value to 
this new era of development cooperation. To this end, greater efforts are needed to communicate its model and engage in international policy debates proactively, for example, by working with like-minded donors in Asia. Japan should make unique contributions to international development in a way that reflects Japan's dual experience as latecomer and donor. Based on the reform efforts and institutional foundations built in the recent decades, now, it should embark on the new era. 


\section{References}

Cabinet Office of the Government of Japan (2011), Opinion Polls on Foreign Policy.

Government of Japan (1992), “Japan's Official Development Assistance Charter,” Cabinet Decisions, June 30.

(2003), “Japan's Official Development Assistance Charter," Economic Cooperation Bureau, August 29.

GRIPS Development Forum, ed. (2008a), Diversity and Complementarity in Development Aid: East Asian Lessons for African Growth, GRIPS Development Forum.

GRIPS Development Forum (2008b), Proposal for a New African Growth Support Initiative, GRIPS Development Forum, Policy Note, No.5, August.

Hausmann, R., Rodrik, D. \& Velasco, A. (2005), “Growth Diagnostics," John F. Kennedy School of Government, Harvard University.

Japan International Cooperation Agency (JICA) \& GRIPS Development Forum (2011), Intellectual Partnership for Africa: Industrial Policy Dialogue between Japan and Ethiopia, December.

Kikuchi, T. (2013), "The Quality and Productivity Improvement Project in Tunisia: A Comparison of Japanese and EU Approaches,” Chapter 8 of Ohno \& Ohno (2013a).

Menocal, A. R. \& Denny, L. (2011), “Locating Japan's ODA within a Crowded and Shifting Marketplace," Informing the Future of Japan's ODA (Part One), Overseas Development Institute, London, July.

Ministry of Foreign Affairs (1999), "Medium-Term Policy on Official Development Assistance," August 10.

February 4.

(2005), “Japan’s Medium-Term Policy on Official Development Assistance,"

(2010), "Enhancing Enlightened National Interest: Living in Harmony with the World and Promoting Peace and Prosperity,” ODA Review Final Report, June.

(2013), Japan's Official Development Assistance White Paper 2012 Japan's International Cooperation, March. 
Ohno, I. (2013), "The Japanese approach to growth support in developing countries: supporting dynamic capacity development," Chapter 7 in Ohno \& Ohno (2013a).

Ohno, I. \& Niiya, Y. (2004), Good Donorship and the Choice of Aid Modalities --Matching Aid with Country Needs and Ownership, GRIPS Development Forum, Tokyo, December.

Ohno, K. \& Ohno, I. (2012), "Dynamic Capacity Development: What Africa Can Learn from Industrial Policy Formulation in East Asia," pp. 221-245, Chapter 7 in Good Growth and Governance in Africa: Rethinking Development Strategies. H. Stein, J. E. Stiglitz, A. Noman, K. Botchwey, eds., Oxford University Press, March.

, eds., (2013a), Eastern and Western Ideas for African Growth: Diversity and Complementality in Development Aid, Routledge, April.

(2013b), "Eastern and Western Ideas for African Growth," published in The World Financial Review, July/August issue.

Organisation for Economic Co-operation and Development (2011), "Busan Partnership for Effective Development Cooperation," Outcome of the 4th High Level Forum on Aid Effectiveness, 29 November-1 December, Busan, Republic of Korea.

http://www. oecd.org/dac/effectiveness/49650173.pdf

United Nations (2013), “A New Global Partnership: Eradicating Poverty and Transform Economies through Sustainable Development," The Report of the High-Level Panel of Eminent Persons on the Post-2015 Development Agenda.

World Bank \& International Finance Corporation (IFC) (2004), Doing Business in 2004: Understanding Regulation, Washington, D.C.

Yanagihara, T. (1998), “Development and Dynamic Efficiency: 'Framework Approach' versus 'Ingredients Approach,' " Chapter 4, pp.70-83, in Ohno K. \& Ohno I., eds., Japanese Views on Economic Development: Diverse Paths to the Market (1998), London, Routledge. 